\title{
A Study on Socio-Economic Back Ground of Basmati Rice Growers in Saharanpur District, India
}

\author{
Akshay Kumar ${ }^{1 *}$, R.N. Yadav ${ }^{1}$, Roop Kumar ${ }^{1}$, Ravindra Kumar ${ }^{1}$, \\ Amit Kumar Mishra ${ }^{1}$, Amit Kumar ${ }^{1}$ and Jagdeep Kumar ${ }^{2}$ \\ ${ }^{1}$ Department of Agricultural Extension and Communication, ${ }^{2}$ Department of Animal Husbandry, \\ College of Agriculture, Sardar Vallabhbhai Patel University of Agriculture and Technology, \\ Meerut-250110, (U.P.), India \\ *Corresponding author
}

\section{A B S T R A C T}

The study was conducted in district Saharanpur during 2014 to investigate the socioeconomic profiles of rural rice farmers. To this end, primary data was collected through structured questionnaire using a sample of size eighty allocating to four block selected purposively, each comprising two villages selected on the basis of proportional

\section{Keywords}

Socio-Economic, Basmati, Rice, Respondent, Family.

Article Info Accepted: 29 June 2017 Available Online: 10 July 2017 sampling technique. Rice farmers were found associated with agriculture sector. Major occupations were teaching and daily wage earners. Most of the rice farmers were found educated and semi-medium size category. Most of the respondents were belonging to higher medium age group followed by lower medium age group and young age group category between the age levels and remaining were old age group is Men generally made decisions. Among the hundred farmers $96.25 \%$ were found educated while the remaining $3.75 \%$ were uneducated which showed high degree of illiteracy level. Villagers used to derive their food sustenance from their own farm products. Cattle and buffalo were the major livestock. the majority of 66.25 per cent respondents were having low level of farm assets followed by 23.27 per cent respondents were having medium level of farm assets and the remaining 10.00 per cent respondents of basmati rice growers were high numbers of farm assets. The major sources of income were farm incomes and foreign remittances. The major heads of expenditures were food items, clothing, education, health, electricity, house rent, sui-gas, and water and investment activities. The total expenditures recorded were Rs. 25,001 to 50000 annual ranges per year. They were found engaged in subsistence level of farming. The Govt. should take steps to improve their standard of living.

\section{Introduction}

Rice is the lifeline for Asians as it is not only a dominant food crop but also an important crop in the national economy. It accounts for a major share of cereal consumption, ranging from $40 \%$ in India to $97 \%$ in Myanmar. Rice contributes $30-76 \%$ of total daily calorie intake by Hossain and Pingali (1998). Therefore, boosting rice production and making rice available to consumers at affordable prices is always at the top of the political agenda for national governments for economic growth, social security, and political stability of the continent. Recent food inflation further alerted Asian countries to keep rice development strategy and policy as a top priority in order to sustain food 
security. There is no single solution to the challenge of global food security, instead, many options are available to sustainably improve rice systems and enhance the overall performance of the global rice economy to reduce poverty and hunger. Priorities will differ greatly among countries and even within countries.

Rice is one of the most important staple food for developing world as well as majority of Asian countries. Rice (Oryza sativa L.) is belongs to Gramineae family. Rice is the major source of calories for more than half of the global population. It contains $6-12 \%$ protein, $70-80 \%$ carbohydrate, $1.2-2.0 \%$ mineral matter and significant content of fats and vitamins. Rice supplies $23 \%$ of global human/ capita energy and $16 \%$ of per capita protein requirements. The geographical distribution of rice extends from $8^{0} \mathrm{~N}$ latitude to $34^{0} \mathrm{~N}$ latitude. The earliest varieties are harvested in 85 to 90 days and late takes 240 days. Rice is considered a short-day plant; varieties may be sensitive or insensitive to day length and temperature or both. The cultivated rice species Oryza sativa is originated in the tropics of South Asia. The cultivated rice belongs to genus Oryza and there are about 25 species of rice distributed in tropical, sub- tropical and warm temperate regions of the worlds by FAO 2010. India is the second largest producer and consumer of rice in the world. Rice production in India crossed the mark of 100 million MT in 201112 accounting for $22.81 \%$ of global production in that year. The productivity of rice has $2372 \mathrm{~kg}$ per hectare in 2011-12 by Anonymous, 2013.

\section{Materials and Methods}

District Saharanpur was the universe of the study. Fourblock of district Saharanpur (Rampur Maniharan, Balliakheri, Puwarka, and Sarsawa) were selected on the basis of purposive sampling technique. Two villages from each block have been selected on the basis of proportional sampling technique. For the analysis primary data was used. A sample of eighty farmers was used. Primary data was personally collected from the respondents through structured questionnaire. The questionnaire was based on both closed and open form questions. The data was usually collected in the farmer's fields, homes or in community centers (KVK). Simple averages, classification and tabulation were used for the analysis of the data.

\section{Research tools applied}

Data were collected with the help of pre structured interview schedule covering all aspect of the present study. To make the procedure and information reliable and accurate, the researcher himself collected data with every individual respondent either at his farm or at his home. Interview schedule was developed and used for collecting information comprehensively. Before collecting information the purpose of the interview data collection and study as a whole were explained to the respondents.

Statistical methods and analytical tools used for measuring and analyzing the data in the study were-

\section{Tabular analysis}

For comparison and interpretation of various aspects, viz. assessing the extent of knowledge, socio-economic status of basmati rice growers and constraints responsible, tabular analysis was used.

\section{Percentage}

Simple comparison has been made on the basis of percentage. For obtaining percent, the frequency of a particular cell was multiplied 
by 100 and divided by the total number of respondents in that particular category to which all of them belonged. The formula used to calculate the percentage is given below-

\section{Percentage $=\frac{\text { Frequancy }}{\text { number of respondants }} \times 100$}

\section{Results and Discussion}

The study provided the following information regarding the socioeconomic profiles of rural rice farmers of district Saharanpur:

\section{Occupation and family size}

Agricultural sector was the main stay of the local community and most of population was related either directly or indirectly with it. The economy of the district was predominantly agriculture-based. Other occupations in the district included teaching and daily wage earners but these activities also supported farming. It was also observed that people engaged in those activities only after they had completed their seasonal farming duties, so we will not count those activities as primary occupations. The average family size was found 5-8 per household. They used to live in joint family system. The average size of the family is highest among Muslims (6.48 persons) followed by Hindus (5.57 persons), Sikhs (4.00 persons). It is also evident that 32.46 per cent of the Muslim households have 7-9 persons as compared to 16.81 per cent of Hindu household. Similarly 17.80 per cent of surveyed Muslim households have 9 persons and above versus 9 per cent of the Hindu households with 9 persons and above. Thus, the analysis has shown that the average size of the family in not only highest among Muslim households but the proportion of Muslim households with larger family size (7 persons and above) is relatively higher also as compared to other religious groups in Saharanpur district by Tyagi (2008) (Table 2).

\section{Age}

The data was collected and categorized in four groups. Most of the respondents were belonging to higher medium age group. Out of the total sample size, maximum 47.50 per cent respondents were belong to higher medium age group (46 to 60 years), followed by 25.00 per cent respondents were belong to lower medium age group (31 to 45 years) and 15.00 per cent respondents were belong to young age group category between the age levels of (15 to 30 years) and remaining 12.50 per cent respondents were old age group is (above - 60 years). The above results clearly indicate that the most of the respondents were belong to higher medium age group.

\section{Education level}

The education level 28.00 per cent of the rural population of Saharanpur district is still illiterate. It is found that proportion of population decreases as the level of education rises. In total, less than two per cent of the population has higher education. Among different religious groups, illiteracy has been found to be the highest (39.15 per cent) among the Muslims. However, the percentage of Muslims population in primary education is highest, indicating to a fact that the Muslim in rural areas of Saharanpur district are sending higher percentage of their children to primary schools and if they do not drop out in between, Muslims would be able to catch up other religious groups in attainment of basic education in the district. Muslims are also lagging behind the Hindus in terms of attainment of higher/technical education in the district. The enrollment seems to be lower in all the classes in view of the fact that each primary school average number of teachers should be 5 and the teacher-student's ratio 
should be 40 by Tyagi, 2008. Among the hundred farmers $96.25 \%$ were found educated while the remaining $3.75 \%$ were uneducated which showed high degree of illiteracy level (Table 1).

\section{Size of land holding}

Households possessed different sizes of land ownership. Some households have both lowland and upland paddy fields. In the field survey it was observed that most of the farmers were tenants. They don't possess their own land and so large portions of their produce were exploited from them. In the research area $11.25 \%, 16.25 \%, 28.00 \%$ and $42.50 \%$ were found both marginal and large size, small, medium and semi-medium size category respectively (Table 3 ).

\section{Type of houses}

Types of houses are included as economic factor in the study. The data in table 7 indicates that most of the 78.75 per cent respondents were having pucca houses of concrete. Only 21.25 per cent respondents were having mixed type of houses, kachcha houses were not found for any respondents of the study areas.

\section{Livestock}

Animal husbandry was another subsidiary income for the villagers and also provided a good source of the family's dietary needs. Cattle, buffalo, cow and poultry were the major livestock there. Those animals were occasionally sold but rarely consumed by the villagers. Poultry were more consumed than sold. Within the villages, grazing lands were limited. However, it was common practice for villagers to feed their livestock on free grazing lands. During the dry season rice straw was fed to the animals (Table 4).

\section{Farm assets}

The data presented in the table 6 revealed that the majority of 66.25 per cent respondents were having low level of farm assets (less than 5 numbers), followed by 23.27 per cent respondents were having medium level of farm assets (between 6 to 10 numbers) and the remaining 10.00 per cent respondents of basmati rice growers were high numbers (more than 10 numbers) of farm assets. This shows that there was dearth of farm assets and equipment in basmati rice cultivation (Table $6)$.

\section{Sources of Income}

The large number of 47.50 per cent respondents was belong to the income of Rs 25,001 to 50000 annual range categories. While 31.25 per cent respondents were belong to income of above Rs 50000/- annual range and remaining 21.25 per cent respondents were belong to the income Rs of up to 25,000 annual range category (Table 5). On average a rice farmer would probably have a cow or two from which he would be able to sell milk and he may keep small stock such as goats, sheeps or poultry. A kitchen garden and a small provision farm would yield fresh vegetables for home consumption, and perhaps a small surplus for sale. He may have a plot of Maize, which yields a couple of hundred rupees or so, although some farmers used to enjoy nonagriculture incomes but out of all other sources of income, agriculture was the main source of income of the rice farmers. Some farmers have their own shops in the villages while some were found investing their incomes in animal trade. The trend of investment in bonds was too low because their saving level was substandard which showed that they were relying on subsistence level of farming. However some members of the family were found engaged in other occupations. Mostly, they were carpenters and 
public school teachers and very few of them were Govt. servants. Foreign remittances were also the main component of nonagriculture incomes.

Table.1 Frequency and percentage distribution of respondent according to their education status

\begin{tabular}{|l|l|l|l|}
\hline S. No. & Educational status & Frequency & Percentage \\
\hline 1 & Illiterate & 3 & 3.75 \\
\hline 2 & Read and Write only & 9 & 11.25 \\
\hline 3 & Primary school & 3 & 3.75 \\
\hline 4 & Middle school & 8 & 8.75 \\
\hline 5 & High school & 27 & 33.75 \\
\hline 6 & Intermediate & 17 & 21.75 \\
\hline 7 & Graduate & 10 & 12.50 \\
\hline 8 & Post graduate and above & 4 & 5.00 \\
\hline
\end{tabular}

Table.2 Frequency and percentage distribution of respondents according to their size of family

\begin{tabular}{|l|l|l|l|}
\hline S. No. & Size of family & Frequency & Percentage \\
\hline 1 & Small size $(1-4$ members) & 26 & 32.50 \\
\hline 2 & Medium size (5- 8 members) & 41 & 51.25 \\
\hline 3 & Large size (more than 8 members) & 13 & 16.25 \\
\hline
\end{tabular}

Table.3 Frequency and percentage distribution of respondents according to their agricultural landholding

\begin{tabular}{|l|l|l|l|}
\hline S. No. & Land holding & Frequency & Percentage \\
\hline 1 & Marginal (below 2.5 acres $)$ & 9 & 11.25 \\
\hline 2 & Small $(2.5-5.00$ acres $)$ & 13 & 16.25 \\
\hline 3 & Semi - medium $(5.00-10.00$ acres $)$ & 34 & 42.50 \\
\hline 4 & Medium $(10-25$ acres $)$ & 23 & 28.75 \\
\hline 5 & Large ( more than 25.00 acres $)$ & 9 & 11.25 \\
\hline
\end{tabular}

Table.4 Frequency and percentage distribution of respondents according to their type of livestock position

\begin{tabular}{|l|l|l|l|}
\hline S. No. & Animal dairy size & Frequency & Percentage \\
\hline 1 & Small dairy size (1-3 milch animals or 10 small animals) & 34 & 42.50 \\
\hline 2 & Medium dairy size (4-6 milch animals or 20 small animals) & 37 & 46.25 \\
\hline 3 & $\begin{array}{l}\text { large dairy size (more than 6 more than animals or more } \\
\text { than 20 small animals) }\end{array}$ & 9 & 11.25 \\
\hline
\end{tabular}

Table.5 Frequency and percentage distribution of family annual income

\begin{tabular}{|l|l|l|l|}
\hline S. No. & Annual income & Frequency & Percentage \\
\hline 1. & Up to 25,000 & 17 & 21.25 \\
\hline 2. & 25,001 to 50,000 & 38 & 47.50 \\
\hline 3. & Above 50,000 & 25 & 31.25 \\
\hline
\end{tabular}


Table.6 Frequency and percentage the category wise distribution of respondents according to available farm assets

\begin{tabular}{|l|l|l|l|}
\hline S. No. & Category & Frequency & Percentage \\
\hline 1 & Low $(<5)$ & 53 & 66.25 \\
\hline 2 & Medium $(6-10)$ & 19 & 23.27 \\
\hline 3 & High $(>10)$ & 8 & 10.00 \\
\hline
\end{tabular}

Table.7 Frequency and percentage distribution of respondents according to type of house they possess

\begin{tabular}{|l|l|l|l|}
\hline S. No. & Type of house & Frequency & Percentage \\
\hline 1 & Kachcha house & 00 & 00 \\
\hline 2 & Mixed house (kachcha+ pucca) & 17 & 21.25 \\
\hline 3 & Pucca house & 63 & 78.75 \\
\hline
\end{tabular}

Table.8 Frequency and percentage distribution of respondents according to their age

\begin{tabular}{|l|l|l|l|}
\hline S. NO. & Age & Frequency & Percentage \\
\hline 1 & Young age group (15 -30 year) & 12 & 15.00 \\
\hline 2 & Lover medium age group (31- 45 year) & 20 & 25.00 \\
\hline 3 & Higher medium age group $(46-60$ year) & 38 & 47.50 \\
\hline 4 & Old age group (above 60 year) & 10 & 12.50 \\
\hline
\end{tabular}

Table.9 Productions of major field crops

\begin{tabular}{|c|c|c|c|c|c|c|c|c|}
\hline \multirow{3}{*}{$\begin{array}{l}\text { Major } \\
\text { field } \\
\text { crops } \\
\text { cultivated }\end{array}$} & \multicolumn{8}{|c|}{ Area ('000 ha) } \\
\hline & \multicolumn{3}{|c|}{ Kharif } & \multicolumn{3}{|l|}{ Rabi } & \multirow[b]{2}{*}{ summer } & \multirow[b]{2}{*}{$\begin{array}{l}\text { Grand } \\
\text { total }\end{array}$} \\
\hline & Irrigated & Rainfed & Total & Irrigated & Rainfed & Total & & \\
\hline Rice & 51.884 & & 51.884 & & & & & 51.884 \\
\hline Wheat & & & & 139.35 & & 139.35 & & 139.35 \\
\hline Sugarcane & & & & 140.825 & & 140.825 & & 140.825 \\
\hline Maize & & 5.258 & 5.258 & & & & 2.541 & 7.799 \\
\hline Barley & & & & & 0.267 & 0.267 & & 0.267 \\
\hline Mustard & & & & 1.061 & & 1.061 & & 1.061 \\
\hline Sesame & & & & & 3.516 & 3.516 & & 3.516 \\
\hline
\end{tabular}

\section{Conclusion and Recommendations}

From the facts and figures it can be observed that Basmati rice farmers were characterized by subsistence level of farming. The average family size was found 5-8 per household, which was higher than Statistical Bulletin, 2006, District Saharanpur. Major occupations were teaching and daily wage earners but these activities also supported agriculture. There was lack of sufficient medical facilities for rice farmers. Most of the rice farmers were found educated and semi-medium size category. The average size of land holding was observed as 5.00-10.00 acres. There was free mobility of labor from area to area. Men generally made decisions. Agriculture was the primary employer and main source of 
livelihood of rural area. Villagers used to derive their food sustenance from their own farm products. Cattle, buffalo, cow and poultry were the major livestock. The major sources of income were farm incomes and foreign remittances. The major heads of expenditures were food items, clothing, education, health, electricity, house rent, suigas, water and investment activities. The total expenditures recorded were Rs. 25,001 to 50000 annual ranges per year. The farmers should utilize their income on economic pursuits so as to improve their standard of living. Govt. should made efforts to provide basic facilities to the rice farmers. The finding of this research study that most of the respondents were under the category of higher medium age group (Tables 8 and 9), engaged in farming, belong to the other backward caste and pausing semi-medium size of holding, involved in the cultivation of basmati rice and other crop and livestock like cow and buffalo to bring economic status and higher medium age group respondents innovative to take interest for the technological gap.

\section{Acknowledgments}

The authors are highly thankful Director of Research, S.V.P. University of Agriculture and Technology, Meerut for providing necessary facilities and funds for present research work.

\section{References}

FAO. 2010. Rice is one of the most importance staple food for developing world. USA.

State. Uttar Pradesh. 2008-09. Agriculture
Contingency Plan for District:

Saharanpur, pp- 3-4.

Annual, report. 2013. India grain and feed annual report. basmati rice production. The crop site.

Hossain, M., and P.L. Pingali. 1998. Rice research technological progress, and impact on productivity and poverty: an overview. In Pingali, P.L. \& Hossain, M. eds. Impact of Rice Res., Los Baños, Philippines, IRRI.

Tyagi, R.C. 2008. Base line survey in the minority concentrated districts of Uttar Pradesh. Ministry of minority affairs government of India New Delhi, pp 1436.

Naeem-ur-Rehman, Khattak and Anwar, Hussain. 2008. An Analysis of socioeconomic profile of rural rice farmers in district swat, Sarhad J. Agric., 24(2): 377-382.

Goswami, S.N., Chaturvedi, A., and Gawande, R.S. 2012. Economics and resource use efficiency of rice farming in Gondia District of Maharashtra. Agri. Situation in India, 68(10): 521-527.

Hiralal, Jana and Verma, H.K. 2004. Association of the paddy growers' sociopersonal traits with their knowledge level on recommended plant protection practices in West Bengal. Environ. Ecol., 22(3): 517-520.

Maji, A.T., Shaibu, A.A., Ibrahim, P.A., Awotide, B., Nwilene, F., Ayinzat, F., Shehu, B., Ojehomon, V., Kura, Y., AsuObi, M., and Danbaba, N. 2012. Emergency rice initiative: socioeconomic analysis of rice farmers in Nigeria. African J. Agri. Res., 7(46): 6150-6157.

\section{How to cite this article:}

Akshay Kumar, R.N. Yadav, Roop Kumar, Ravindra Kumar, Amit Kumar Mishra, Amit Kumar and Jagdeep Kumar. 2017. A Study on Socio-Economic Back Ground of Basmati Rice Growers in Saharanpur District. Int.J.Curr.Microbiol.App.Sci. 6(7): 2817-2823. doi: https://doi.org/10.20546/ijcmas.2017.607.392 